JRPB, Vol. 7, No. 1, Maret 2019, Hal. 52-65

DOI: $10.29303 /$ jrpb.v7i1.109

ISSN 2301-8119, e-ISSN 2443-1354

Tersedia online di http://jrpb.unram.ac.id/

\title{
KAJIAN PROSES DAN ANALISIS KELAYAKAN FINANSIAL USAHA UBI CILEMBU BAKAR
}

\author{
Process Review and Financial Feasibility Analysis of Cilembu Sweet Potato Baking
}

\author{
Ahmad Thoriq ${ }^{1, *)}$, Asri Widyasanti ${ }^{1}$ \\ ${ }^{1}$ Departemen Teknik Pertanian dan Biosistem, Fakultas Teknologi Industri Pertanian \\ Universitas Padjadjaran, Jl. Raya Bandung Sumedang KM 21, Jatinangor 40600 \\ Email $^{*}$ : thoriq@unpad.ac.id \\ Diterima: Desember 2018 \\ Disetujui: Maret 2019
}

\begin{abstract}
Cilembu sweet potato are local superior varieties from Cilembu Village, Sumedang Regency. Sweet taste like honey is produced through the process of planting at a certain height, ripening after post-harvest, and baked using an oven. The characteristics of the roasting process are an important part that influences the feasibility of a cilembu sweet potato business, so this study aims to conduct a process study and analyze the financial feasibility of cilembu sweet potato roasting business. The method used in this study is an experimental method that was collaborated with descriptive methods to analyze the financial feasibility of roasted cilembu sweet potato business. The results showed that the average temperature of the grill room was $138^{\circ} \mathrm{C}$, effective roasting capacity of $6.64 \mathrm{~kg} / \mathrm{hour}$, consumption rate of LPG $0.44 \mathrm{~kg} / \mathrm{hour}$, rate of decrease in average weight of Cilembu sweet potato during the roasting process of 5.66 grams per minutes for grade $C$ and 3.68 grams per minute for grade $B$ with yields of roasted cilembu sweet potato produced at $77.38 \%$ and weights of $22.62 \%$. Based on the financial feasibility analysis HPP obtained was Rp 14,132.72/kg, NPV was Rp $73,154,539 /$ month, BCR was 1.28, IRR was $20.06 \%$, and capital will return in the eighth month.
\end{abstract}

Keywords: business analysis, oven, baking, cilembu sweet potato

\begin{abstract}
ABSTRAK
Ubi cilembu merupakan varietas unggul lokal asal Desa Cilembu Kabupaten Sumedang. Rasa yang manis seperti madu dihasilkan melalui proses penanaman pada ketinggian tertentu, pemeraman setelah pasca panen, dan pemanggangan menggunakan oven. Karakteristik proses pemanggangan merupakan bagian penting yang mempengaruhi kelayakan usaha ubi cilembu bakar. Penelitian ini bertujuan melakukan kajian proses dan menganalisis kelayakan finansial usaha pemanggangan ubi cilembu. Metode yang digunakan pada penelitian ini adalah metode ekperimen yang dikolaborasikan dengan metode deskriptif untuk menganalisis kelayakan finansial usaha ubi cilembu bakar. Hasil penelitian menunjukkan bahwa suhu ratarata ruang pemanggang adalah $138^{\circ} \mathrm{C}$, kapasitas efektif pemanggangan $6,64 \mathrm{~kg} / \mathrm{jam}$, laju
\end{abstract}


konsumsi LPG 0,44 kg/jam, Laju penurunan berat rata-rata ubi cilembu selama proses pemanggangan 5,66 gram per menit untuk grade $C$ dan 3,68 gram per menit untuk grade $B$ dengan rendemen ubi cilembu pangang yang dihasilkan sebesar 77,38\% dan bobot sebesar 22,62\%. Berdasarkan analisis kelayakan finansial didapatkan HPP Rp 14.132,72/kg, NPV Rp 73.154.539/bulan, BCR 1,28, IRR 20,06\% dan modal akan kembali pada bulan kedelapan.

Kata kunci: analisis usaha, oven, pemanggangan, ubi cilembu

\section{PENDAHULUAN}

\section{Latar Belakang}

Ubi cilembu merupakan jenis ubi jalar yang memiliki rasa seperti madu dan aroma yang khas saat dipanggang menggunakan oven. Ubi cilembu juga telah terdaftar dalam indikasi geografis dengan nomor ID IG 000000019 tanggal 20 April 2013 yang menunjukkan bahwa ubi cilembu memiliki kekhasan yang tidak dimiliki daerah lain. Usahatani ubi cilembu di Kabupaten Sumedang menguntungkan secara ekonomi dan memiliki dayasaing yang baik dilihat dari keunggulan kompetitif maupun keunggulan komparatif (Hoeridah dan Suriati, 2011). Petani ubi cilembu saat ini tercatat sebanyak 1591 orang yang menanami lahan seluas 462,03 hektar. Lokasi penanaman ubi cilembu tersebar di 34 Desa yang terdapat di empat kecamatan, yaitu Kecamatan Tanjung Sari, Rancakalong, Pamulihan dan Sukasari Kabupaten Sumedang (ASAGUCI, 2013).

Ubi cilembu yang besar dan memiliki rasa yang manis seperti madu dihasilkan dari budidaya yang dilakukan pada tempat yang memiliki suhu tanah $17-24^{\circ} \mathrm{C}$, dan dilakukan proses pemeraman setelah pasca panen (Amalia, 2010). Kemanisan ubi cilembu dipengaruhi oleh sifat kimia, fisik tanah, elevasi, iklim dan pemeraman selama dua minggu setelah panen (Solihin, dkk., 2017). Selama penyimpanan $3-5$ minggu susut bobot ubi akan meningkat, sedang kadar air daging ubi dan kadar pati tidak berbeda (Onggo, 2006). Selain proses budidaya dan pasca panen, rasa enak, manis, legit dan bermadu hanya akan diperoleh jika ubi cilembu dipanggang menggunakan oven (ASAGUCI, 2013). Sehingga ubi cilembu yang dipasarkan di dalam negeri dijual dalam bentuk mentah dan panggang sedangkan ubi cilembu yang dipasarkan keluar negeri hanya dalam bentuk mentah (Hoeridah dan Suriati, 2011).

Pemanggangan ubi cilembu saat ini dilakukan menggunakan oven dengan bahan bakar Liquified Petroleum Gas (LPG). Oven dengan bahan bakar gas telah banyak dimanfaatkan industri kecil menengah pengolahan pangan, hal ini karena penggunaan bahan bakar LPG terbukti lebih efisien dan memiliki panas bermanfaat lebih tinggi dibandingkan dengan bahan bakar biomasa, minyak tanah, arang, dan listrik (Syukur, 2009). Ubi cilembu yang telah dipanggang menggunakan oven berbahan bakar gas memberikan keuntungan sebesar $89,32 \%$, sedangkan ubi cilembu mentah memberikan keuntungan sebesar $10,68 \%$ dari total keuntungan seluruhnya (Vindy, 2014). Namun demikian, penelitian tersebut tidak menggungkap karakteristik proses pemanggangan yang justru merupakan bagian penting yang mempengaruhi kelayakan suatu usaha ubi cilembu bakar. Oleh karena itu, pada penelitian ini dilakukan kajian proses pemanggangan ubi cilembu dan dilakukan analisis kelayakan finansial usaha ubi cilembu bakar.

\section{Tujuan Penelitian}

Penelitian ini bertujuan melakukan kajian proses pemanggangan ubi cilembu yang meliputi: 1) kapasitas efektif pemangganan, 2) laju konsumsi bahan bakar Liquified Petroleum Gas (LPG), 3) rendemen dan bobot ubi cilembu panggang, dan 4) laju penurunan berat ubi cilembu selama proses pemanggangan

Selain itu, penelitian ini juga bertujuan melakukan analisis finansial meliputi harga pokok produksi (HPP), Nett 
Present Value (NPV), Benefit Cost Rasio (BCR) dan Internal Rate of Return (IRR).

\section{METODE PENELITIAN}

\section{Waktu dan Tempat}

Penelitian dilakukan pada bulan Juli sampai September 2018 bertempat di usaha pemanggangan ubi cilembu Desa Cilayung, Kecamatan Jatinangor.

\section{Alat dan Bahan}

Bahan baku yang digunakan pada penelitian ini adalah ubi cilembu yang telah disimpan selama lebih dari sepuluh hari, dengan ukuran grade B $(100-200$ gram/umbi) dan grade $C(<100$ gram per umbi) (SNI Nomor 01-4493-1998). Ubi cilembu yang digunakan pada penelitian ini berasal dari Kecamatan Sukasari Kabupaten Sumedang. Pemilihan sumber bahan baku dari Kecamatan Sukasari karena Kecamatan Sukasari termasuk salah satu lokasi penanaman ubi cilembu berdasarkan indikasi geografis dengan nomor ID IG 000000019 tanggal 20 April 2013 (ASAGUCI, 2013).

Peralatan yang digunakan pada penelitian ini adalah oven satu pintu dengan bahan bakar gas dan dilengkapi dengan indikator suhu. Bagian ruang pemanggangan berukuran $(80 \times 44 \times 57)$ $\mathrm{cm}$. Sedangkan peralatan yang digunakan untuk uji kinerja oven dapat dilihat pada tabel 1 .

Tabel 1. Peralatan Uji Kinerja Oven

\begin{tabular}{|c|c|c|}
\hline No & $\begin{array}{c}\text { Nama } \\
\text { Peralatan }\end{array}$ & Fungsi \\
\hline 1 & Stop watch & $\begin{array}{l}\text { Mengukur waktu } \\
\text { pemanggangan }\end{array}$ \\
\hline 2 & Meteran & $\begin{array}{l}\text { Mengukur dimensi } \\
\text { oven }\end{array}$ \\
\hline 3 & $\begin{array}{l}\text { Timbangan } \\
\text { digital }\end{array}$ & $\begin{array}{l}\text { Mengukur berat ubi } \\
\text { cilembu sebelum dan } \\
\text { selama proses } \\
\text { pemanggangan }\end{array}$ \\
\hline 4 & Alat tulis & $\begin{array}{l}\text { Mencatat data hasil } \\
\text { pengukuran }\end{array}$ \\
\hline
\end{tabular}

\section{Metode Pengambilan Data}

Data pengukuran selama proses pemanggangan ubi cilembu terdiri atas berat ubi cilembu selama proses pemanggangan, suhu ruang pemanggangan, dan konsumsi LPG terpakai.

Pengamatan dilakukan sebanyak empat kali ulangan untuk masing-masing proses pemanggangan ubi cilembu grade $\mathrm{B}$ dan grade $\mathrm{C}$ pada kondisi oven terisi penuh. Kapasitas maksimum oven terisi penuh berkisar antara 10 - $12 \mathrm{~kg}$ ubi cilembu.

Berat ubi cilembu selama proses pemanggangan diamati dengan metode sampling dari ubi cilembu grade B dan ubi cilembu grade $\mathrm{C}$ dengan cara ditimbang tiap 10 menit. Suhu ruang pemanggang diamati tiap 10 menit melalui indikator suhu yang terpasang pada pintu oven. Konsumsi LPG terpakai selama proses pemanggangan diamati berdasarkan perubahan berat timbangan tabung gas berikut isinya menggunakan timbangan digital.

Data yang digunakan untuk analisis kelayakan finansial berupa data primer dan sekunder. Data primer berupa data hasil wawancara mendalam (indepth interview) dengan pengelola usaha pemanggangan ubi cilembu yang terdiri atas biaya investasi, biaya tetap dan biaya variabel usaha ubi cilembu bakar. Sedangkan data sekunder dikumpulkan melalui publikasi ilmiah yang berkenaan dengan pengolahan ubi cilembu.

\section{Parameter Proses Pemanggangan Ubi Cilembu}

Beberapa parameter kinerja pamanggangan ubi cilembu yang dianalisis antara lain:

1. Kapasitas Efektif Pemangganan

Kapasitas efektif menunjukkan kemampuan oven dalam melakukan proses pemanggangan ubi cilembu persatuan waktu. Kapasitas efektif pemanggangan dihitung menggunakan persamaan 1 (Wulandani dan Utari, 2013) sebagai berikut.

$$
\mathrm{K}_{\mathrm{ep}}=\frac{\mathrm{m}_{\mathrm{f}}}{\Delta \mathrm{t}}
$$


Dimana $\mathrm{K}_{\mathrm{ep}}$ merupakan kapasitas efektif pemanggangan (kg/jam), $\mathrm{m}_{\mathrm{f}}$ adalah berat ubi cilembu setelah pemanggangan $(\mathrm{kg})$, dan $\Delta t$ adalah waktu pemanggangan ubi cilembu (detik).

2. Laju konsumsi bahan bakar LPG

Laju konsumsi bahan bakar LPG merupakan banyaknya bahan bakar yang digunakan selama proses pemanggangan persatuan waktu yang dihitung menggunakan persamaan 2 (Wulandani dan Utari, 2013) sebagai berikut.

$V_{g}=\frac{\left(B_{g 1}-B_{t g}\right)-\left(B_{g 2}-B_{t g}\right)}{\Delta t}$

Dimana $V_{g}$ adalah konsumsi bahan bakar LPG (kg/jam), $B_{g 1}$ adalah berat tabung gas + isi sebelum pemanggangan $(\mathrm{kg}), B_{g 2}$ adalah berat tabung gas + isi setelah pemanggangan $(\mathrm{kg})$, dan $B_{t g}$ adalah berat tabung gas $(\mathrm{kg})$.

3. Rendemen dan bobot ubi cilembu panggang

Rendemen merupakan persentase banyaknya berat ubi yang tersedia setelah proses pemanggangan, sedangkan bobot merupakan persentase banyaknya berat ubi yang hilang selama proses pemanggangan. Rendemen dihitung menggunakan persamaan 3, sedangkan bobot dihitung menggunakan persamaan 4 (Wulandani dan Utari, 2013) sebagai berikut.

$\mathrm{R}_{\mathrm{uc}}=\frac{\mathrm{m}_{\mathrm{f}}}{\mathrm{m}_{0}} \times 100 \%$
$\mathrm{~B}_{\mathrm{b}}=\frac{\mathrm{m}_{\mathrm{f}-\mathrm{m}_{0}}}{\mathrm{~m}_{0}} \times 100 \%$

Dimana $\mathrm{R}_{\mathrm{uc}}$ adalah rendemen ubi cilembu dalam satuan (\%), dan $\mathrm{B}_{\mathrm{b}}$ adalah bobot ubi cilembu (\%). $\mathrm{m}_{\mathrm{f}}$ adalah berat ubi cilembu setelah pemanggangan $(\mathrm{kg})$, dan $\mathrm{m}_{0}$ adalah berat awal ubi cilembu sebelum proses pemanggangan $(\mathrm{kg})$

4. Laju penurunan berat ubi cilembu selama proses pemanggangan

Laju penurunan berat ubi cilembu selama proses pemanggangan merupakan berkurangnya berat ubi cilembu selama proses pemanggangan persatuan waktu yang dihitung menggunakan persamaan 5
(Wulandani dan Utari, 2013) sebagai berikut.

$\frac{\mathrm{dM}}{\mathrm{dt}}=\frac{\mathrm{m}_{\mathrm{f}}-\mathrm{m}_{\mathrm{o}}}{\Delta \mathrm{t}}$

\section{Parameter Analisis Kelayakan Finansial Usaha Ubi Cilembu Bakar}

Perhitungan kelayakan finansial diawali dengan menghitung besarnya biaya penyusutan peralatan produksi menggunakan metode garis lurus yang dirumuskan sebagai berikut.

$\mathrm{D}=\frac{\mathrm{P}-\mathrm{S}}{\mathrm{N}}$.

Dimana D merupakan biaya penyusutan pertahun (Rp/tahun), $\mathrm{P}$ adalah harga awal peralatan (Rp), S adalah harga akhir peralatan $(\mathrm{Rp})$ dan $\mathrm{N}$ adalah perkiraan umur ekonomis (tahun). Sedangkan besarnya anggsuran pinjaman diperhitungkan menggunakan persamaan bunga anuitas dengan bunga tetap (Thoriq, dkk., 2018) sebagai berikut:

$\mathrm{A}=\mathrm{P} *(\mathrm{i} / 12)^{*}(1+\mathrm{i} / 12) \mathrm{n} /(1+\mathrm{i} / 12) \mathrm{n}-1$

Dimana, A merupakan besarnya angsuran yang harus dibayarkan (Rp/bulan), $\mathrm{P}$ adalah besarnya pinjaman $(\mathrm{Rp}), \mathrm{n}$ adalah lama pinjaman (tahun) dan i adalah suku bunga (\%/tahun). Besarnya suku bunga yang diacu pada penelitian ini adalah suku bunga kredit usaha rakyat mikro PT. Bank Republik Indonesia, Tbk., yaitu sebesar 7\% efektif per-tahun.

Suatu usaha dikatakan layak apabila Nett Present Value (NPV) >0, Benefit Cost Ratio (BCR) > 1, Internal Rate of Return (IRR) > Suku bunga MARR, dan pengembalian modal yang cepat. Besarnya NPV, dan BCR dihitung menggunakan persamaan berikut (Kastaman, 2004).

$\mathrm{NPV}=(\Sigma$ PVin $)(\Sigma$ PVout $)$.
$B C R=\frac{(\Sigma \text { PVin })}{(\text { EVVout })} \ldots \ldots \ldots \ldots \ldots$

Dimana PVin merupakan nilai sekarang bersih dari perhitungan dana masuk, PVout merupakan nilai sekarang bersih dari perhitungan dana keluar selama jangka waktu analisis. Sedangkan 
perhitungan IRR menggunakan fungsi yang terdapat pada Microsoft office excel berdasarkan data pendapatan bersih selama jangka waktu analisis, yaitu 24 bulan menggunakan persamaan 10.

IRR(data ke-1 : data ke-24)

\section{HASIL DAN PEMBAHASAN}

\section{Konstruksi Oven Pemanggang Ubi Cilembu}

Oven pemanggang ubi cilembu menggunakan bahan bakar gas berukuran panjang $80 \mathrm{~cm}$, lebar $44 \mathrm{~cm}$, dan tinggi 57 cm; memiliki 2 rak pemanggang dengan ukuran $40 \times 60 \mathrm{~cm}$. Terdapat peredam panas pada dinding bagian kanan, dinding bagian kiri dan bagian pintu oven serta terdapat indikator suhu yang dipasangkan pada bagian pintu oven. Oven tersebut merupakan buatan pabrik dan tersedia di pasaran. Hal ini menunjukkan bahwa oven tersebut telah dilakukan uji kinerja dan keamanan operasional. Konstruksi oven pemanggan ubi cilembu secara lebih rinci dapat dilihat pada Gambar 1.

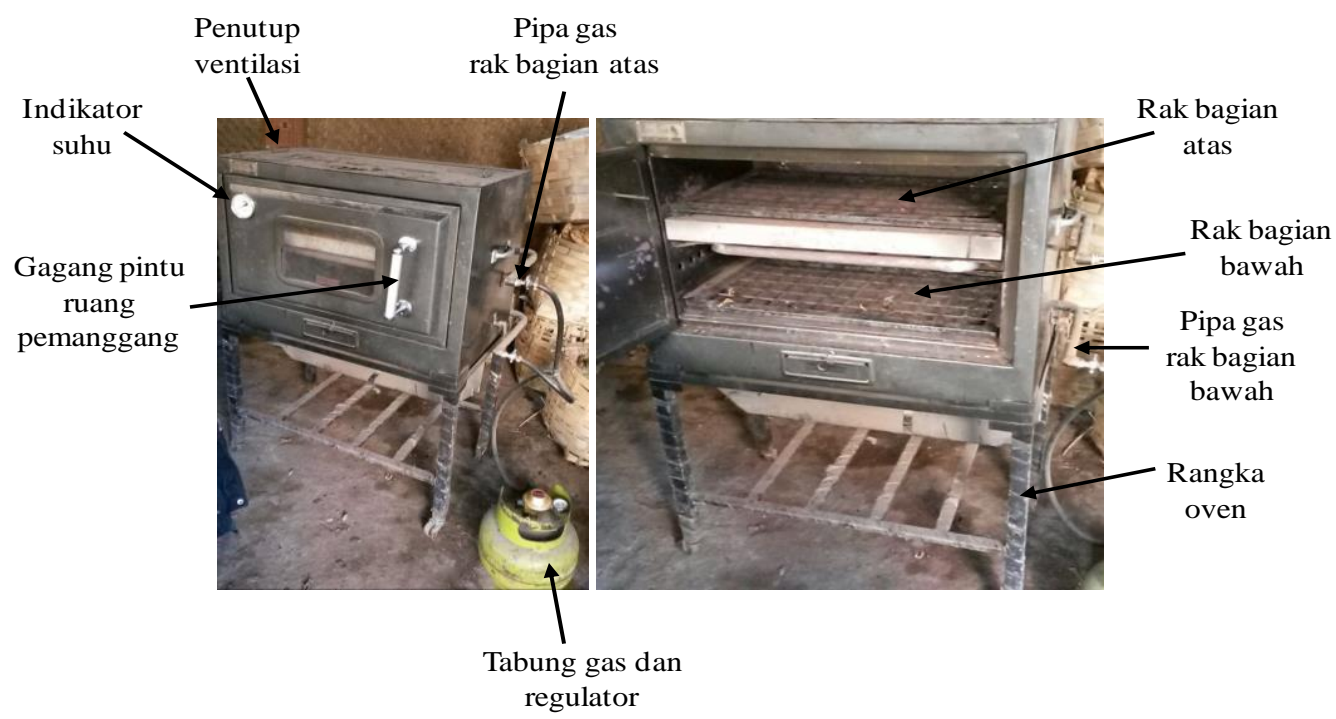

Gambar 1. Konstruksi Oven Pemanggang Ubi Cilembu

Sebelum proses pemanggangan, dilakukan proses sortasi berdasarkan ukuran. Ubi dengan ukuran yang sama dimasukkan dan disusun pada rak pemanggang. Selanjutnya kran gas yang terletak pada bagian samping dinding pemanggang dibuka setengah bukaan. Hal ini bertujuan untuk mendapatkan ubi cilembu yang matang luar dalam. Jika kran gas dibuka lebih dari setenggah bukaan, maka ubi cilembu yang dipanggang hanya bagian luar saja yang terlihat matang, sedangkan bagian dalam masih belum matang. Ketika suhu oven telah mencapai $150^{\circ} \mathrm{C}$, pekerja mengecek ubi yang dipanggang. Jika kondisi fisik telah lunak, maka dilakukan proses pembalikan. Proses pembalikan dilakukan secara manual penjepit yang terbuat dari bilah bambu.

\section{Kapasitas Efektif dan Laju Konsumsi LPG}

Kapasitas efektif pemanggangan merupakan banyaknya ubi yang telah dipanggang persatuan waktu proses pemanggangan. Sedangkan konsumsi LPG merupakan banyaknya gas yang terpakai selama proses pemanggangan persatuan waktu pemanggangan. Data hasil pengujian empat kali ulangan pemanggangan ubi cilembu dapat dilihat pada tabel 2 sebagai berikut. 
Tabel 2. Kapasitas oven dan laju konsumsi LPG

\begin{tabular}{ccccccc}
\hline No & $\begin{array}{c}\text { Berat } \\
\text { Awal } \\
(\text { gram })\end{array}$ & $\begin{array}{c}\text { Berat } \\
\text { Akhir } \\
(\text { gram })\end{array}$ & $\begin{array}{c}\text { Lama } \\
\text { Pemanggangan } \\
\text { (detik) }\end{array}$ & $\begin{array}{c}\text { Kapasitas efektif } \\
\text { pemanggangan } \\
(\mathrm{kg} / \text { jam })\end{array}$ & $\begin{array}{c}\text { Konsumsi } \\
\text { LPG } \\
(\text { gram })\end{array}$ & $\begin{array}{c}\text { Laju } \\
\text { Konsumsi } \\
\text { LPG } \\
(\text { Kg/jam })\end{array}$ \\
\hline 1 & 10.000 & 8.000 & 4.263 & 6,76 & 500 & 0,42 \\
2 & 11.000 & 8.500 & 4.205 & 7,28 & 500 & 0,43 \\
3 & 10.000 & 7.700 & 4.569 & 6,07 & 540 & 0,43 \\
4 & 11.000 & 8.300 & 4.584 & 6,52 & 630 & 0,49 \\
\hline $\begin{array}{c}\text { Rata- } \\
\text { rata }\end{array}$ & $\mathbf{1 0 . 5 0 0}$ & $\mathbf{8 . 1 2 5}$ & $\mathbf{4 . 4 0 5}$ & $\mathbf{6 , 6 4}$ & $\mathbf{5 4 3}$ & $\mathbf{0 , 4 4}$ \\
\hline
\end{tabular}

Berdasarkan tabel 2 terlihat bahwa rata-rata kapasitas efektif pemanggangan adalah sebesar $6,64 \mathrm{~kg} / \mathrm{jam}$ dan rata-rata laju konsumsi LPG adalah sebesar $0,44 \mathrm{~kg} / \mathrm{jam}$.

\section{Rendemen dan Bobot Ubi Cilembu Panggang}

Rata-rata berat awal ubi cilembu yang dipanggang dalam sekali proses pemanggangan adalah $10,50 \mathrm{~kg}$ dengan kadar air awal 73,29 (\% bb), setelah melalui proses pemanggangan selama 1,22 jam berat ubi cilembu menjadi $8,13 \mathrm{~kg}$ dengan kadar air 56,71 (\% bb). Berdasarkan perhitungan menggunakan persamaan 3 diperoleh rendemen ubi cilembu sebesar $77,38 \%$ dan bobot sebesar $22,62 \%$.

\section{Laju Penurunan Berat Ubi Cilembu dan Profil Suhu Selama Proses} Pemanggangan

Laju penurunan berat ubi dihitung berdasarkan penurunan kadar air umbi selama proses pemanggangan. Penurunan berat umbi selama proses pemanggangan disebabkan karena berkurangnya kadar air yang terdapat pada ubi cilembu. Data hasil pengamatan hubungan berat ubi cilembu berdasarkan waktu pemanggangan dapat dilihat pada Gambar 2.

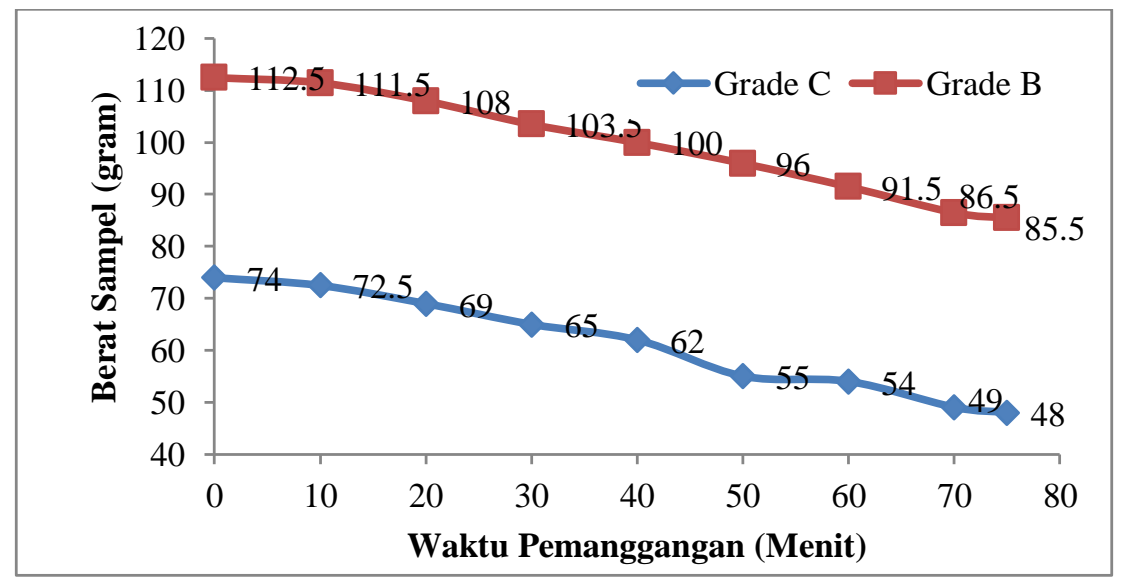

Gambar 2. Hubungan Berat Ubi Cilembu berdasarkan Waktu Pemanggangan

Berdasarkan gambar 2 penurunan kadar air ubi cilembu yang dipanggang terjadi secara bertahap dengan laju rata-rata sebesar 5,66 gram per menit untuk grade $\mathrm{C}$ dan 3,68 gram per menit untuk grade $B$. Hal ini menunjukkan bahwa semakin besar ukuran ubi, maka penurunan berat ubi akan semakin kecil. Faktor lain yang mempengaruhi penurunan berat ubi adalah suhu pada ruang pemanggang, semakin tinggi suhu pada ruang pemanggang, maka pengurangan bobot ubi cilembu yang dipanggang akan semakin tinggi. Namun demikian, suhu pemanggangan harus terjaga di bawah $200^{\circ} \mathrm{C}$. Bila suhu pemanggangan lebih dari $200^{\circ} \mathrm{C}$, maka ubi cilembu yang 
dipanggang hanya bagian luar saja yang terlihat matang, sedangkan bagian dalam masih mentah. Berdasarkan hasil pengamatan, hubungan suhu dan waktu pemanggangan dapat dilihat pada gambar 3 .

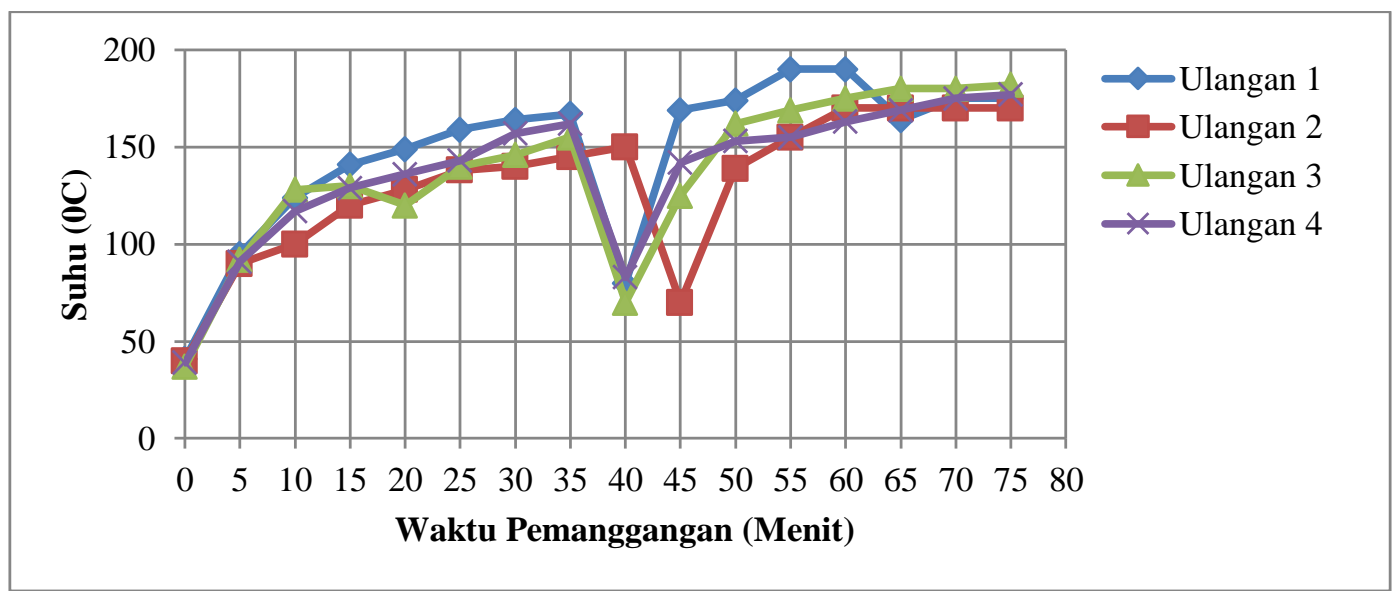

Gambar 3. Hubungan Suhu dan Waktu Pemanggangan Ubi Cilembu

Berdasarkan gambar 3 terlihat bahwa suhu oven naik seiring bertambahnya waktu, namun menurun secara signifikan pada menit ke 40 hingga 45 . Hal ini disebabkan pada waktu tersebut terjadi proses pembalikan ubi cilembu dimana pekerja harus membuka pintu oven yang menyebabkan menurunnya suhu secara signifikan karena dipengaruhi oleh suhu lingkungan. Adanya waktu delay selama 5 menit pada ulangan 2 dibandingkan ulangan lainnya disebabkan karena pekerja usaha ubi cilembu bakar melakukan pembalikan pada menit ke-45. Sedangkan pada pengamatan ulangan 1, ulangan 3 dan ulangan 4 pembalikan dilakukan pada menit ke 40 . Penentuan proses pembalikan didasarkan pada kondisi ubi cilembu yang dipanggang. Jika dirasa telah empuk atau matang, maka dilakukan pembalikan, kondisi tersebut umumnya dilakukan pada menit ke 40 hingga menit ke 45 waktu pemanggangan. Setelah pembalikan selesai dan pintu oven ditutup kembali, suhu di dalam ruang pemanggang akan kembali mengalami kenaikan sampai mencapai kurang lebih $175^{\circ} \mathrm{C}$ yang terjadi pada menit ke 75 dan ubi cilembu yang dipanggang telah matang.

\section{Analisis Kelayakan Finansial Usaha Pemanggangan Ubi Cilembu \\ Perhitungan kelayakan finansial} diawali dengan penentuan biaya investasi peralatan, selanjutnya ditentukan variabel asumsi dari usaha yang akan dilakukan. Rincian biaya investasi dapat dilihat pada tabel 3.

Tabel 3. Biaya investasi usaha pemanggangan ubi cilembu

\begin{tabular}{clccrr}
\hline No & Nama peralatan & Jumlah & Satuan & Harga Satuan (Rp) & Harga Total (Rp) \\
\hline 1 & Keranjang plastik 30 kg & 30 & Buah & 55.000 & 1.650 .000 \\
2 & Ember besar 30 liter & 4 & Buah & 60.000 & 240.000 \\
3 & Oven bahan bakar gas & 1 & Unit & 2.500 .000 & 2.500 .000 \\
4 & Tabung gas 3 kg & 2 & Unit & 150.000 & 300.000 \\
5 & Pisau & 4 & Buah & 30.000 & 120.000 \\
6 & Baskom besar & 4 & Buah & 35.000 & 140.000 \\
7 & Keranjang bambu & 2 & Buah & 30.000 & 60.000 \\
\hline Jumlah $($ Rp) & & & & $\mathbf{5 . 0 1 0 . 0 0 0}$ \\
\hline
\end{tabular}


Besarnya nilai investasi tersebut digunakan untuk menghitung besarnya biaya penyusutan peralatan dan bunga modal yang akan mempengaruhi biaya produksi. Biaya penyusutan diperhitungkan menggunakan metode garis lurus, sedangkan biaya bunga modal berasal dari asumsi bahwa seluruh biaya investasi peralatan dan modal kerja pembelian bahan baku dalam satu bulan adalah dana pinjaman dari lembaga keuangan. Banyaknya bahan baku usaha pemanggangan ubi cilembu dalam satu bulan diperhitungkan berdasarkan kapasitas oven 10,5 kg/proses. Dengan asumsi dilakukan 4 kali pemanggangan dalam satu hari dan 25 hari kerja dalam satu bulan, sehingga banyaknya bahan baku ubi cilembu adalah $1050 \mathrm{~kg} / \mathrm{bulan}$. Secara umum bahan baku yang digunakan termasuk ke dalam grade $\mathrm{C}$ dengan berat lebih kecil dari 100 gram/umbi, hal ini karena grade B dan grade A di jual dalam bentuk mentah ke daerah lain atau ke tengkulak untuk kepentingan ekspor. Selain itu, ubi cilembu grade $\mathrm{C}$ membutuhkan waktu pemanggangan yang lebih cepat dibandingkan dengan grade B dan grade A. Harga ubi cilembu mentah dengan ukuran grade $\mathrm{C}$ di tingkat pedagang pengumpul adalah Rp 5000/kg, sehingga biaya bahan baku dalam satu bulan adalah $\mathrm{Rp}$ $5.250 .000 /$ bulan.

Berdasarkan perhitungan tersebut, maka besanya dana yang harus dipinjam ke lembaga keuangan adalah $\mathrm{Rp}$ 10.465.200 yang merupakan penjumlahan dari biaya investasi ditambah biaya bahan baku, biaya administrasi dan asuransi pinjaman (2\% dari pinjaman) untuk skema pinjaman 2 tahun dengan tingkat suku bunga KUR 7\% pertahun.

Perhitungan biaya produksi dilakukan berdasarkan data dan beberapa asumsi (Wijayanti, dkk., 2011; Pertiwi dan Purnama, 2011; Thoriq, dkk., 2018) yang dapat dilihat pada tabel 4 .

Tabel 4. Variabel Asumsi Produksi Ubi Cilembu Bakar

\begin{tabular}{|c|c|c|c|c|}
\hline No & Uraian & Mekanis & Satuan & Keterangan \\
\hline 1 & Umur Proyek & 2 & tahun & Asumsi \\
\hline 2 & Suku Bunga Bank & 7 & $\%$ efektif & $\begin{array}{l}\text { Kredit Usaha } \\
\text { Rakyat (KUR) }\end{array}$ \\
\hline 3 & Nilai rongsok peralatan & 10 & $\%$ dari harga investasi & Asumsi \\
\hline 4 & Biaya perawatan peralatan & 2 & $\%$ dari biaya investasi & Asumsi \\
\hline 5 & Biaya sewa tempat usaha & 2.000 .000 & Rp/tahun & Asumsi \\
\hline 6 & Manajemen usaha & 1.000 .000 & Rp/bulan & Asumsi \\
\hline 7 & Kapasitas Oven & 10,50 & $\mathrm{~kg} /$ proses & Pengukuran \\
\hline 8 & Jumlah pemanggangan & 4 & kali proses/hari & Asumsi \\
\hline 9 & Jam kerja (hari) & 8 & Jam/hari & Kondisi real \\
\hline 10 & Jam kerja (bulan) & 25 & hari/bulan & Kondisi real \\
\hline 11 & Upah kerja & 70.000 & Rp/hari & Kondisi real \\
\hline 12 & Jumlah tenaga kerja harian & 2 & orang & Kondisi real \\
\hline 13 & Konsumsi Bahan bakar gas & 0,53 & $\mathrm{~kg} /$ proses & Pengukuran \\
\hline 14 & Harga gas non subsidi & 12.500 & $\mathrm{Rp} / \mathrm{kg}$ & Harga pasaran \\
\hline 15 & Biaya bahan bakar gas & 666.250 & Rp/bulan & Perhitungan \\
\hline 16 & $\begin{array}{l}\text { Harga ubi cilembu mentah } \\
\text { grade } \mathrm{C}\end{array}$ & 5.000 & $\mathrm{Rp} / \mathrm{kg}$ & Kondisi real \\
\hline 17 & Jumlah bahan baku & 1.050 & $\mathrm{Kg} / \mathrm{bulan}$ & Perhitungan \\
\hline 18 & $\begin{array}{l}\text { Biaya bahan baku ubi } \\
\text { cilembu }\end{array}$ & 5.250 .000 & $\mathrm{Rp} / \mathrm{Kg}$ & Perhitungan \\
\hline 19 & Rendemen & 77,38 & $\%$ & Perhitungan \\
\hline 20 & Ubi cilembu bakar yang & 812,49 & $\mathrm{Kg} / \mathrm{bulan}$ & Bahan baku x \\
\hline
\end{tabular}




\begin{tabular}{|c|c|c|c|c|}
\hline No & Uraian & Mekanis & Satuan & Keterangan \\
\hline & dihasilkan & & & rendemen \\
\hline 21 & $\begin{array}{l}\text { Harga kemasan (kapasitas } \\
1 \mathrm{~kg} \text { ) }\end{array}$ & 200 & Rp/kemasan & Asumsi \\
\hline 22 & Biaya Kemasan & 162.498 & Rp/bulan & Perhitungan \\
\hline 23 & Konsumsi air & 0,50 & kubik / hari & Asumsi \\
\hline 24 & Harga air & 5.000 & Rp/kubik & Kondisi real \\
\hline 25 & $\begin{array}{l}\text { Biaya konsumsi air + } \\
\text { abodemen }\end{array}$ & 72.500 & Rp/bulan & Perhitungan \\
\hline
\end{tabular}

\section{Penentuan Biaya Produksi dan Harga Pokok Produksi}

Biaya produksi ubi cilembu bakar dipengaruhi oleh biaya tetap dan biaya variabel. Bila usaha dikelola secara professional, maka dalam perhitungan biaya tetap diasumsikan mengeluarkan biaya sewa tempat dan biaya manajemen usaha (karyawan tetap pengelola usaha) (Thoriq dan Sampurno, 2016; Thoriq dkk, 2017, Thoriq dkk, 2018). Sedangkan biaya penyusutan diperhitungkan menggunakan metode garis lurus (persamaan 6) dan biaya bunga modal dihitung menggunakan persamaan 7 , maka berdasarkan perhitungan dengan menggunakan data pada tabel 4, besarnya biaya tetap dapat dilihat pada tabel 5.

Tabel 5. Biaya Tetap Usaha Produksi Ubi Cilembu Bakar

\begin{tabular}{clr}
\hline No & Komponen Biaya & \multicolumn{1}{c}{$\begin{array}{c}\text { Biaya } \\
\text { (Rp/bulan) }\end{array}$} \\
\hline 1 & $\begin{array}{l}\text { Biaya penyusutan } \\
\text { peralatan }\end{array}$ & 187.875 \\
2 & $\begin{array}{l}\text { Biaya sewa tempat } \\
\text { usaha }\end{array}$ & 166.667 \\
3 & $\begin{array}{l}\text { Biaya perawatan } \\
\text { peralatan }\end{array}$ & 8.350 \\
4 & $\begin{array}{l}\text { Manajemen usaha } \\
\text { Angsuran pinjaman } \\
\text { (pokok + bungga) }\end{array}$ & 1.000 .000 \\
& 468.554 \\
\hline & Total (Rp) & $\mathbf{1 . 8 3 1 . 4 4 6}$ \\
\hline
\end{tabular}

Berdasarkan tabel 5 terlihat bahwa besarnya biaya tetap usaha produksi ubi cilembu bakar adalah Rp 1.831.446/bulan. Sedangkan biaya variabel dengan waktu kerja 25 hari/bulan terdiri atas biaya bahan baku, bahan bakar gas, upah tenaga kerja harian, dan biaya air dan kemasan dengan rincian dapat dilihat pada tabel 6 .

Tabel 6. Biaya variabel usaha produksi ubi cilembu bakar

\begin{tabular}{clr}
\hline No & \multicolumn{1}{c}{$\begin{array}{c}\text { Komponen } \\
\text { Biaya }\end{array}$} & \multicolumn{1}{c}{$\begin{array}{c}\text { Biaya } \\
\text { (Rp/bulan) }\end{array}$} \\
\hline 1 & $\begin{array}{l}\text { Bahan baku ubi } \\
\text { cilembu mentah }\end{array}$ & 5.250 .000 \\
2 & $\begin{array}{l}\text { Upah kerja tenaga } \\
\text { harian }\end{array}$ & 3.500 .000 \\
3 & $\begin{array}{l}\text { Biaya konsumsi } \\
\text { air + abodemen }\end{array}$ & 72.500 \\
4 & $\begin{array}{l}\text { Biaya Bahan } \\
\text { bakar gas } \\
5\end{array}$ & 666.250 \\
Biaya Kemasan & 162.498 \\
\hline & Total $(\mathbf{R p})$ & $\mathbf{9 . 6 5 1 . 2 4 8}$ \\
\hline
\end{tabular}

Berdasarkan tabel 6, terlihat bahwa besarnya biaya variabel usaha produksi ubi cilembu bakar adalah Rp 9.651.248/bulan. Sehingga besarnya biaya produksi yang merupakan penjumlahan biaya tetap dan biaya variabel adalah sebesar $\mathrm{Rp}$ 11.482.69/bulan.

Mengacu pada kapasitas bahan baku yang diproduksi $1050 \mathrm{~kg} / \mathrm{bulan}$ ubi mentah atau $812,49 \mathrm{~kg} / \mathrm{bulan}$ ubi cilembu bakar maka dihasilkan harga pokok produksi (HPP) ubi cilembu bakar Rp 14.132,72/kg.

\section{Payback Period (PBP)}

PBP mengindikasikan seberapa cepat modal atau investasi yang telah dikeluarkan dapat segera kembali berdasarkan pemasukan dan pengeluaran dari usaha yang dilakukan. Pendapatan usaha produksi ubi cilembu bakar didapat dari hasil penjualan ubi cilembu bakar yang diasumsikan pada 
bulan ke-1 sampai bulan ke-3 hanya $60 \%$ ubi cilembu bakar yang terjual, pada bulan ke-4 sampai bulan ke-6 hanya $80 \%$ ubi cilembu bakar yang terjual dan pada bulan ke-7 hingga bulan ke-24 sebanyak 100\% ubi cilembu bakar hasil produksi terjual semua. Rincian pemasukan dan pengeluaran keuangan dapat dilihat pada tabel 7 .

Tabel 7. Pemasukan dan pengeluaran keuangan produksi ubi cilembu bakar

\begin{tabular}{cccc}
\hline Bulan & Pemasukan $(\mathbf{R p} /$ tahun) & Pengeluaran $(\mathbf{R p / b u l a n})$ & Keuntungan $(\mathbf{R p / b u l a n})$ \\
\hline 0 & & 5.010 .000 & $(5.010 .000)$ \\
1 & 9.749 .880 & 11.482 .694 & $(6.742 .814)$ \\
2 & 9.749 .880 & 11.482 .694 & $(8.475 .627)$ \\
3 & 9.749 .880 & 11.482 .694 & $(10.208 .441)$ \\
4 & 12.999 .840 & 11.482 .694 & $(8.691 .295)$ \\
5 & 12.999 .840 & 11.482 .694 & $(7.174 .148)$ \\
6 & 12.999 .840 & 11.482 .694 & $(5.657 .002)$ \\
7 & 16.249 .800 & 11.482 .694 & $(889.896)$ \\
8 & 16.249 .800 & 11.482 .694 & 3.877 .211 \\
9 & 16.249 .800 & 11.482 .694 & 8.644 .317 \\
10 & 16.249 .800 & 11.482 .694 & 13.411 .423 \\
11 & 16.249 .800 & 11.482 .694 & 18.178 .530 \\
12 & 16.249 .800 & 11.482 .694 & 22.945 .636 \\
\hline
\end{tabular}

Berdasarkan Tabel 7 terlihat bahwa saldo bernilai positif pada bulan ke-8 produksi ubi cilembu bakar. Hal ini menunjukkan pada bulan ke-8 usaha produksi ubi cilembu bakar mulai mendapatkan keuntungan atau modal investasi telah kembali.

\section{Net Present Value (NPV) dan Benefit Cost Ratio (BCR)}

Selama periode analisis besarnya pengeluaran berupa investasi peralatan di awal proyek dan biaya produksi yang berasal dari penjumlahan biaya tetap dan biaya variabel. Sedangkan pendapatan usaha berasal dari hasil penjualan ubi cilembu bakar dengan harga pasar Rp. $20.000 / \mathrm{kg}$ dan nilai rongsok mesin produksi.

Besarnya biaya pengeluaran berupa biaya investasi peralatan usaha pada bulan ke-0 sebesar Rp 5.010.000, dan biaya produksi pada bulan ke-1 hingga ke-24 sebesar Rp 11.482.694/bulan, sedangkan pendapatan bulan pertama hingga bulan ketiga usaha produksi ubi cilembu bakar yaitu sebesar Rp 9.749.880/bulan, pada bulan keempat hingga keenam sebesar Rp 12.999.840/bulan, pada bulan ketujuh hingga ke-24 sebesar Rp 16.249.800/bulan dan nilai akhir peralatan yang diasumsikan 10\% dari harga awal yaitu Rp 501.000.

Mengacu pada bunga kredit usaha rakyat (KUR), yaitu sebesar 7\% efektif/tahun didapatkan nilai sekarang pemasukan bersih pada produksi ubi cilembu bakar adalah sebesar Rp 334.631.642/bulan dan besarnya nilai sekarang pengeluaran bersih adalah sebesar Rp 261.477.103/bulan. Dengan menggunakan persamaan (8) didapatkan nilai NPV produksi ubi cilembu bakar sebesar Rp 73.154.539/bulan sedangkan BCR dihitung menggunakan persamaan (9) yaitu sebesar 1,28.

\section{Internal Rate of Return (IRR).}

IRR adalah suatu nilai penunjuk yang identik dengan seberapa besar suku bunga yang dapat diberikan oleh investasi tersebut dibandingkan dengan suku bunga bank yang berlaku umum (suku bunga pasar atau Minimum Attractive Rate of Return / MARR). Suku bunga MARR yang diacu pada penelitian ini adalah suku bunga deposito PT. Bank Republik Indonesia yaitu sebesar 5,6\% efektif perbulan. Pada suku bunga IRR akan diperoleh NPV $=0$. Perhitungan IRR dilakukan menggunakan 
persamaan (7) berdasarkan data pada tabel 5 bulan ke 1 hingga bulan ke 24. Berdasarkan hasil perhitungan besarnya IRR usaha produksi ubi cilembu bakar adalah $20,06 \%$.

\section{Analisis Sensitivitas}

Analisa sensitivitas merupakan analisa yang dilakukan untuk melihat sejauh mana proyek yang akan dijalankan dapat bertahan terhadap perubahan-perubahan yang mungkin terjadi selama berjalannya waktu investasi. Beberapa skenario perubahan pada penelitian ini mengacu pada skenario yang dilakukan Kusuma dan Mayasti (2014), yaitu sebagai berikut.

a. Pendapatan turun $10 \%$ dan pengeluaran bernilai tetap

b. Pengeluaran naik $10 \%$ dan pendapatan tetap

c. Pendapatan turun $10 \%$ diikuti dengan kenaikan pengeluaran naik $10 \%$.

Setelah melakukan analisis sensitivitas dapat diketahui seberapa jauh dampak perubahan tersebut terhadap kelayakan proyek. Hasil simulasi analisis sensitivitas dapat dilihat pada tabel 8 .

Tabel 8. Hasil simulasi analisis sensitivitas

\begin{tabular}{|c|c|c|c|c|c|c|}
\hline \multirow[b]{2}{*}{ No } & \multirow[b]{2}{*}{ Parameter Analisis } & \multicolumn{4}{|c|}{ Parameter Kelayakan Investasi } & \multirow[b]{2}{*}{ Keterangar } \\
\hline & & $\begin{array}{c}\text { NPV } \\
\text { (Rp/bulan) }\end{array}$ & BCR & $\begin{array}{l}\text { IRR } \\
(\%)\end{array}$ & $\begin{array}{c}\text { PBP } \\
\text { (bulan) }\end{array}$ & \\
\hline 1 & Hasil analisis awal & 73.154 .539 & 1,28 & 20,06 & 8 & layak \\
\hline 2 & $\begin{array}{l}\text { Pendapatan turun } 10 \% \\
\text { dan pengeluaran bernilai } \\
\text { tetap }\end{array}$ & 39.734 .947 & 1,15 & 8,80 & 10 & layak \\
\hline 3 & $\begin{array}{l}\text { Pengeluaran naik } 10 \% \\
\text { dan pendapatan tetap }\end{array}$ & 47.050 .401 & 1,16 & 9,95 & 10 & layak \\
\hline 4 & $\begin{array}{l}\text { Pendapatan turun } 10 \% \\
\text { diikuti dengan kenaikan } \\
\text { pengeluaran } 10 \% \text {. }\end{array}$ & 13.630 .810 & 1,05 & 4,70 & 16 & tidak layak \\
\hline
\end{tabular}

Berdasarkan tabel 8 terlihat bahwa pada skenario penurunan maupun kenaikan pendapatan sebesar $10 \%$ usaha ubi cilembu bakar masih layak untuk dijalankan. Sedangkan pada skenario pendapatan turun $10 \%$ diikuti dengan kenaikan pengeluaran $10 \%$, maka usaha ubi cilembu bakar tidak layak untuk dijalankan karena nilai IRR sebesar 4,7\% lebih kecil dibandingkan dengan suku bunga MARR sebesar 5,6\% efektif perbulan.

\section{KESIMPULAN}

Rata-rata berat ubi cilembu yang dipanggang sebanyak $10,5 \mathrm{~kg}$ per proses dihasilkan kapasitas efektif pemanggangan 6,64 kg/jam dengan laju konsumsi bahan bakar gas sebanyak $0,44 \mathrm{~kg} / \mathrm{jam}$ pada suhu ruang pemanggang rata-rata $138^{\circ} \mathrm{C}$. Rendemen ubi cilembu yang dihasilkan adalah sebesar $77,38 \%$ dan bobot sebesar $22,62 \%$.

Pada kapasitas bahan baku mentah sebanyak $1.050 \mathrm{~kg} / \mathrm{bulan}$ didapatkan biaya produksi sebesar Rp 11.482.694/bulan dan harga pokok produksi sebesar Rp $14.132,72 / \mathrm{kg}$. Bila ubi cilembu bakar dijual dengan harga pasar Rp 20.000/kg dengan asumsi pada bulan ke-1 sampai bulan ke-3 hanya $60 \%$ yang terjual, bulan ke-4 sampai bulan ke-6 hanya $80 \%$ yang terjual, dan pada bulan ke-7 bulan ke-24 sebanyak $100 \%$ terjual semua, maka didapatkan NPV sebesar Rp 73.154.539/bulan, BCR sebesar 1,28, IRR sebesar 20,06\% dan modal akan kembali pada bulan kedelapan. Berdasarkan analisis sensitivitas pada skenario penurunan maupun kenaikan pendapatan sebesar $10 \%$ usaha ubi cilembu bakar masih layak untuk dijalankan. Sedangkan pada skenario pendapatan turun $10 \%$ diikuti dengan kenaikan pengeluaran 10\%, maka 
usaha ubi cilembu bakar tidak layak untuk dijalankan karena nilai IRR sebesar 4,7\% lebih kecil dibandingkan dengan Suku bunga MARR, yaitu 5,6\% efektif per bulan.

\section{UCAPAN TERIMAKASIH}

Ucapan terimakasih disampaikan kepada Bapak Anang selaku pemilik usaha kecil menengah ubi cilembu di Desa Cilayung Kecamatan Jatinangor Kabupaten Sumedang yang telah bersedia menjadi objek penelitian dan Muhammad Lutfi mahasiswa Teknik Pertanian Universitas Padjadjaran yang telah membantu penulis dalam mengumpulkan data penelitian.

\section{DAFTAR REFERENSI}

Amalia, G.S. (2010). Mencari Kunci Produktivitas Ubi Jalar Cilembu Dengan Membandingkan Aspek Teknik Budidaya, Aspek Sifat Tanah dan Faktor Lingkungan (Studi Kasus: Desa Cilembu Sumedang dan Desa Cilubang Mekar Bogor). Skripsi. Fakultas Pertanian, Institut Pertanian Bogor.

ASAGUCI (Asosiasi Agribisnis Ubi Cilembu). (2013). Buku Persyaratan Indikasi Geografis Ubi Cilembu Sumedang. Asosiasi Agribisnis Ubi Cilembu dan Pemerintah Kabupaten Sumedang.

Hoeridah A., dan Suriati, T. (2011). Analisis Daya Saing Ubi Jalar Cilembu di Kabupaten Sumedang Jawa Barat. Jurnal Forum Agribisnis 1 (2): 200 216.

Kastaman, R. (2004). Ekonomi Teknik Untuk Pengembangan Kewirausahaan. Bandung (ID); Pustaka Giratuna dan ELOCUNPAD.

Kusuma, P.T.W.W dan N.K.I. Mayasti. (2014). Analisa Kelayakan Finansial Pengembangan Usaha Produksi Komoditas Lokal: Mie Berbasis Jagung. Jurnal Agritech 34 (2): 194 202
Onggo, T.M. (2006). Perubahan Komposisi Pati dan Gula Dua Jenis Ubi Jalar Cilembu Selama Penyimpanan. Jurnal Bionatura 8(2): 161-170.

Pertiwi, S. dan Purnama, D. (2011). Analisis Pra-Investasi Untuk Komersialisasi Alat Pemerah Susu Sapi Semi Otomatis Tipe Engkol di Provinsi Jawa Barat. Jurnal Keteknikan Pertanian 25 (2): 95-102.

Solihin, M.A., Sitorus, S.R.P., Sutandi, A., dan Widiatmaka. (2017). Karakteristik Lahan dan Kualitas Kemanisan Ubi Jalar Cilembu. Jurnal Pengelolaan Sumberdaya Alam dan Lingkungan 7 (3): 251-259.

SNI (Standar Nasional Indonesia). SNI 014493-1998. Ubi Jalar.

Syukur, M.H. 2009. Penggunaan liquified petroleum gases (LPG) upaya mengurangi kecelakaan akibat LPG. Jurnal Forum Teknologi 1 (2): 1 - 14.

Thoriq A., dan Sampurno R.M. (2016). Analisis Ekonomi Aplikasi Mesin Pemarut Sagu di Kabupaten Teluk Bintuni Papua Barat. Jurnal Teknologi Pertanian 17 (2): 129-138.

Thoriq A., Sampurno, R.M. dan. Nurjanah, S. (2017). Evaluasi Ekonomi Teknik Produksi Keripik Kentang Secara Manual (Studi Kasus: Taman Teknologi Pertanian, Cikajang, Kabupaten Garut, Provinsi Jawa Barat). Jurnal Teknotan 11 (2): 43-54.

Thoriq, A., Herwanto, T., dan Ciptaningtyas, D. (2018). Modifikasi Mesin Peniris Minyak dan Kelayakan Finansial Produksi Keripik Bayam. Jurnal Teknik Pertanian Lampung 7 (2): 63-72.

Wijayanti R, Budiastra, I.B., dan Hasbullah, R. (2011). Kajian Rekayasa Proses Penggorengan Hampa Dan Kelayakan Usaha Produksi Keripik Pisang. Jurnal Keteknikan Pertanian 25 (2): 133-140.

Wulandani, D dan Utari, S. (2013). Analisis Pengeringan Sawut Ubi Jalar (Ipomoea batatas L.) Menggunakan Pengering Efek Rumah Kaca (ERK). 
Jurnal Keteknikan Pertanian 1 (1): $151-158$.

Vindy, B. (2014). Analisis Usaha Ubi

Cilembu Mas Pipin di Kecamatan
Padang Timur Kota Padang. Tesis. Fakultas Pertanian. Universitas Andalas. 